\title{
EFFECT OF ACETYLCHOLINE ON DESENSITIZATION OF ISOLATED RAT TRACHEA TO 5-HYDROXYTRYPTAMINE -A POSSIBLE ALLOSTERIC INTERACTION BETWEEN DRUG RECEPTORS
}

\author{
Issei TAKAYANAGI, Yukisato ISHIDA and Keijiro TAKAGI \\ Department of Chemical Pharmacolugy, Faculty of Pharmaceutical Sciences, \\ University of Tokyo, Bunkyo-ku, Tokyo, Japan \\ Received for publication May 19, 1972
}

It is well known that desensitization of smooth muscle preparations occurs by repeated exposure to a stimulating drug. This is called tachyphylaxis. This paper demonstrates the response of isolated rat tracheal muscle to 5-hydroxytryptamine (5-HT) as being diminished by repeated application in almost every instance and that 5-HT applied in the presence of stimulating drugs caused a further contraction when the preparation did not respond to 5-HT alone. For this reason interaction between 5-HT and other stimulating drugs was studied on the rat tracheal muscle after desensitization had occurred.

\section{METHODS}

After sacrificing a male rat ( 190 to $330 \mathrm{~g}$ in body wt.) by a blow on the neck, the trachea was removed and placed in a Petri-dish containing aerated Locke Ringer solution. After removing the adipose tissue, the trachea was incised longitudinally. The opened trachea was transversely cut along ring cartilages into 7 strips, which were then linked with thread (1). The tracheal muscle preparation was suspended in a $20 \mathrm{ml}$ organ bath filled with Locke Ringer solution, $\mathrm{kept}$ at $32 \mathrm{C}$ and bubbled with air. Responses of the preparation to drugs were isotonically recorded through a writing lever (magnification $\times 6$, and weighting $300 \mathrm{mg}$ ). Locke Ringer solution used in this apper had the following composition (mM): $\mathrm{NaCl}, 154 ; \mathrm{KCl} 5.6: \mathrm{CaCl}_{2}, 2.2 ; \mathrm{MgCl}_{2}, 2.1 ; \mathrm{NaHCO}_{3}, 5.9$; glucose, 2.8 .

All experimental results in this paper are expressed as mean of at least 8 experiments.

Drugs used: Agonists: acetylcholine chloride, Histamine hydrochloride, 5-hydroxytryptamine creatinine sulfate, 1-isoprenaline hydrochloride, $\mathrm{KCl}$ and phenylephrine hydrochloride. Antagonists: atropine sulfate, N-benzyl-5-methoxytryptamine hydrochloride (S-8), morphine hydrochloride, propranolol hydrochloride and tetrodotoxin. All drug concentrations refer to the salts and are given in $\mathrm{g} / \mathrm{ml}$. Japan. 

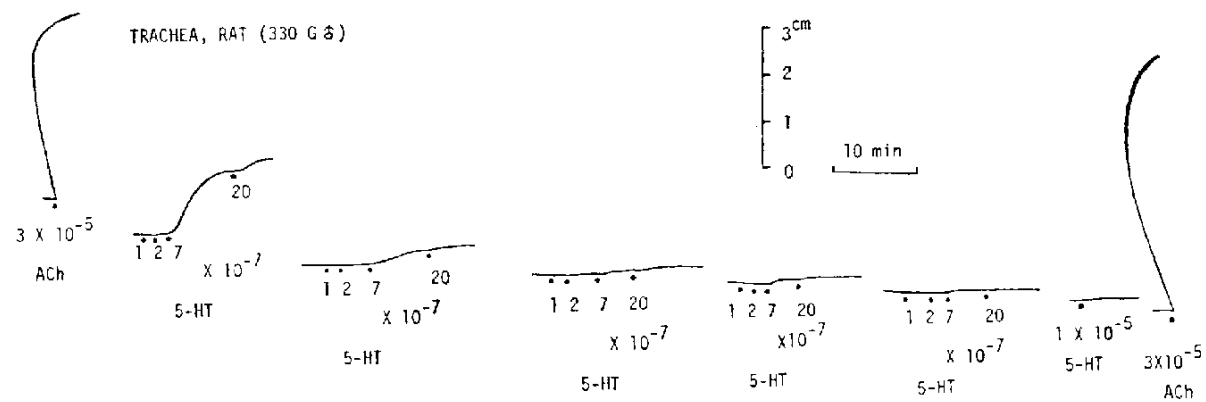

FIG. 1. Desensitization of response of the isolated rat tracheal muscle to 5-HT,
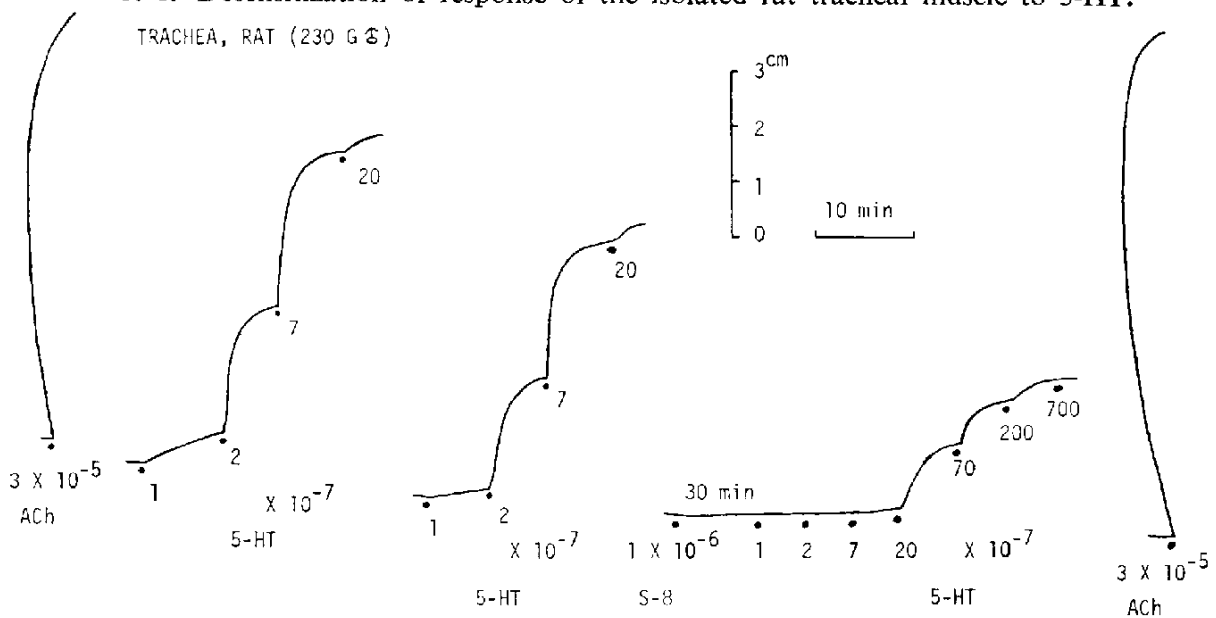

FIG. 2. Antagonism between 5-HT and N-benzyl-5-methoxytryptamine (S-8), TRACLIEA, RAT (190 G 8$)$
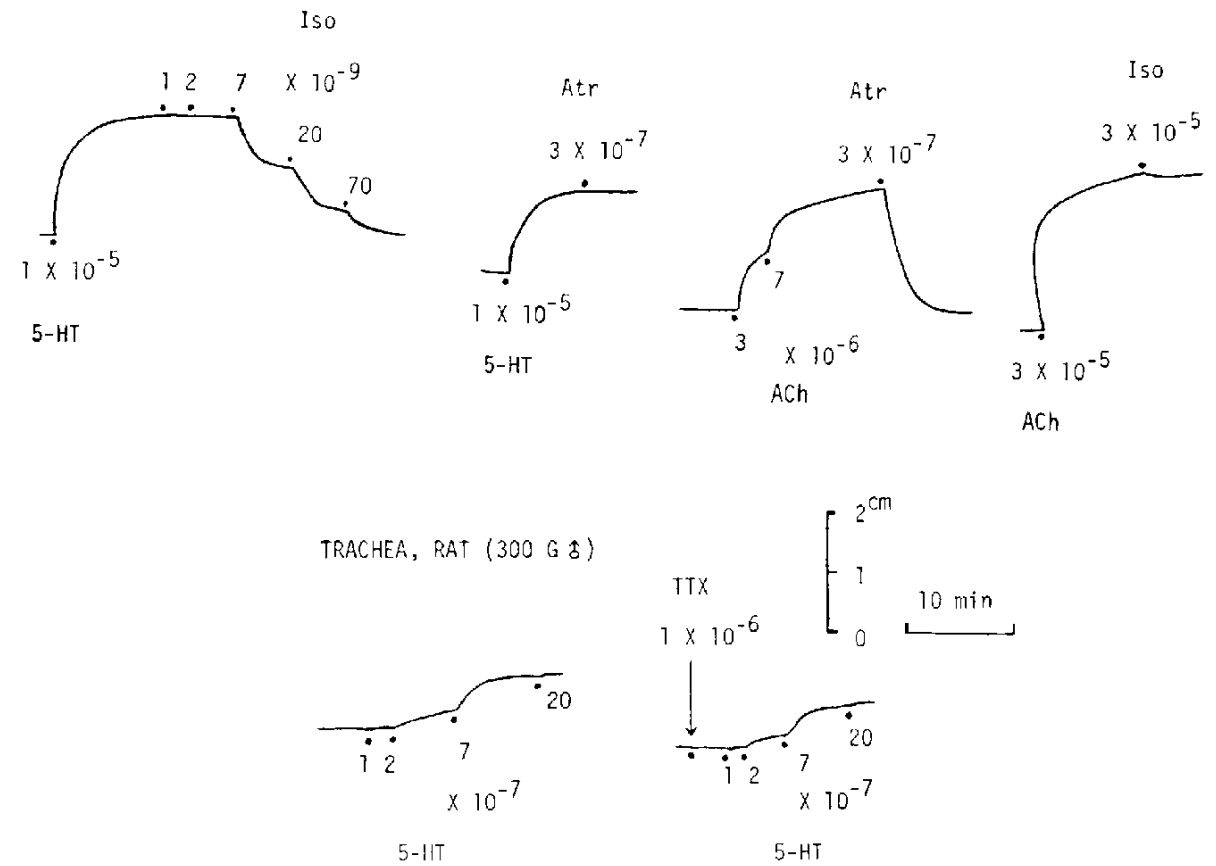

FIG. 3. Effects of isoprenaline (Iso), atropine (Atr) and tetrodotoxin (TTX) on the contraction produced by ACh or 5-HT. 


\section{RESULTS}

\section{5-Hydroxytryptamine $(5-H T)$}

The response to 5-HT was diminished by repeated application in almost every instance. A typical result is shown in Fig. 1, however, response to 5-HT was considerably inhibited by N-benzyl-5-methoxytryptamine hydrochloride (S-8) (2), an inhibitor of 5-HT (Fig. 2) and by isoprenaline (Fig. 2) but was little affected by tetrodotoxin $\left(10^{-6} \mathrm{~g} / \mathrm{ml}\right)$, atropine $\left(3 \times 10^{-7} \mathrm{~g} / \mathrm{ml}\right)$ (Fig. 3) and morphine $\left(10^{-5} \mathrm{~g} / \mathrm{ml}\right)$. Relaxation of 5-HT-induced contraction by isoprenaline was competitively blocked by propranolol (Fig. 4).

In preparations where response to 5-HT was abolished by repeated application, 5-H added in the presence of $\mathrm{ACh}$ resulted in a further contraction (Fig. 5). The action of

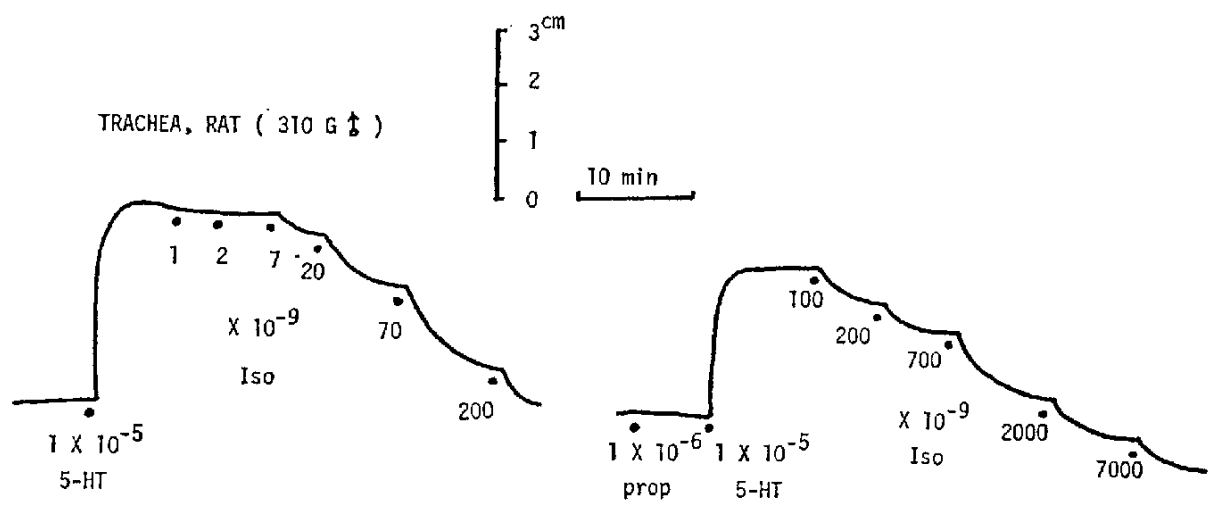

FIG. 4. Antagonism between isoprenaline (Iso) and propranolol (Prop).

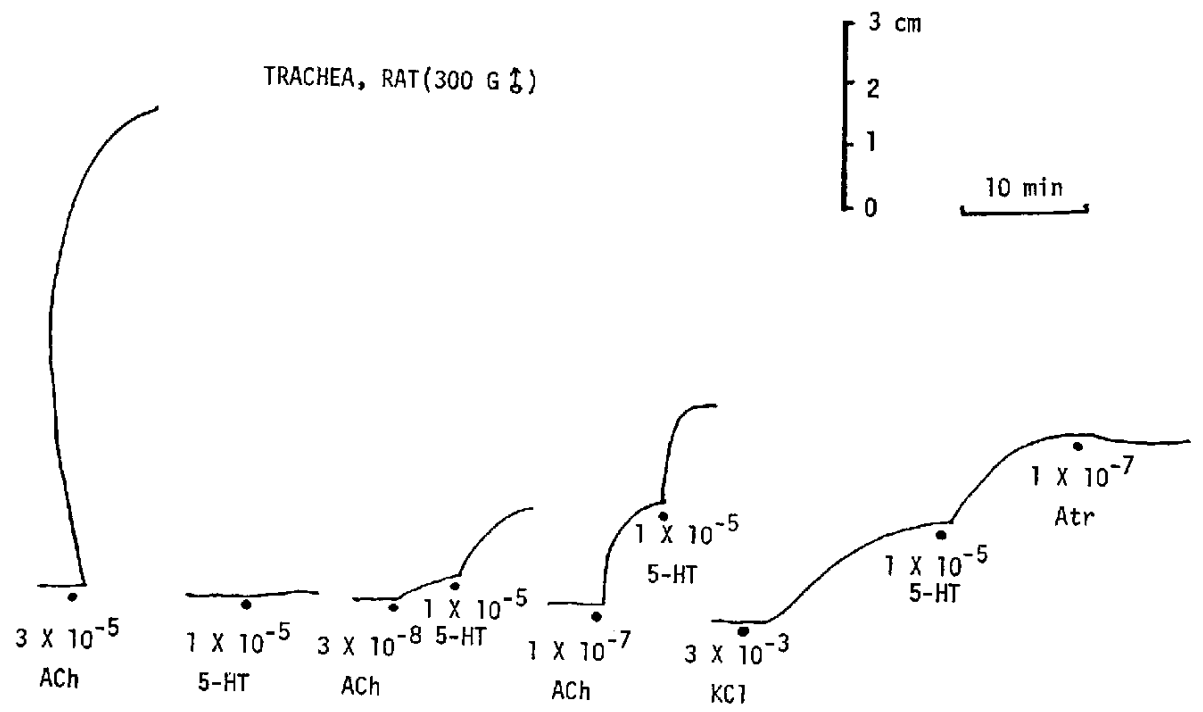

Fig. 5. A further contraction produced by $5-\mathrm{HT}$ in the presence of $\mathrm{ACh}$ or $\mathrm{KCl}$. Experimental results were obtained after response to 5-HT had been abolished by repeated application. 
5-HT in the presence of ACh was not desensitized by repeated application. Further contraction by $5-\mathrm{HT}$ in the presence of $\mathrm{ACh}$ was inhibited by isoprenaline and N-benzyl-5methoxytryptamine hydrochloride (S-8) (Fig. 6) but not by tetrodotoxin (Fig. 6) and morphine. The relaxing effect of isoprenaline was also competitively blocked by propranolol (Fig. 6), however, both the contraction by ACh and the further contraction by 5-HT were
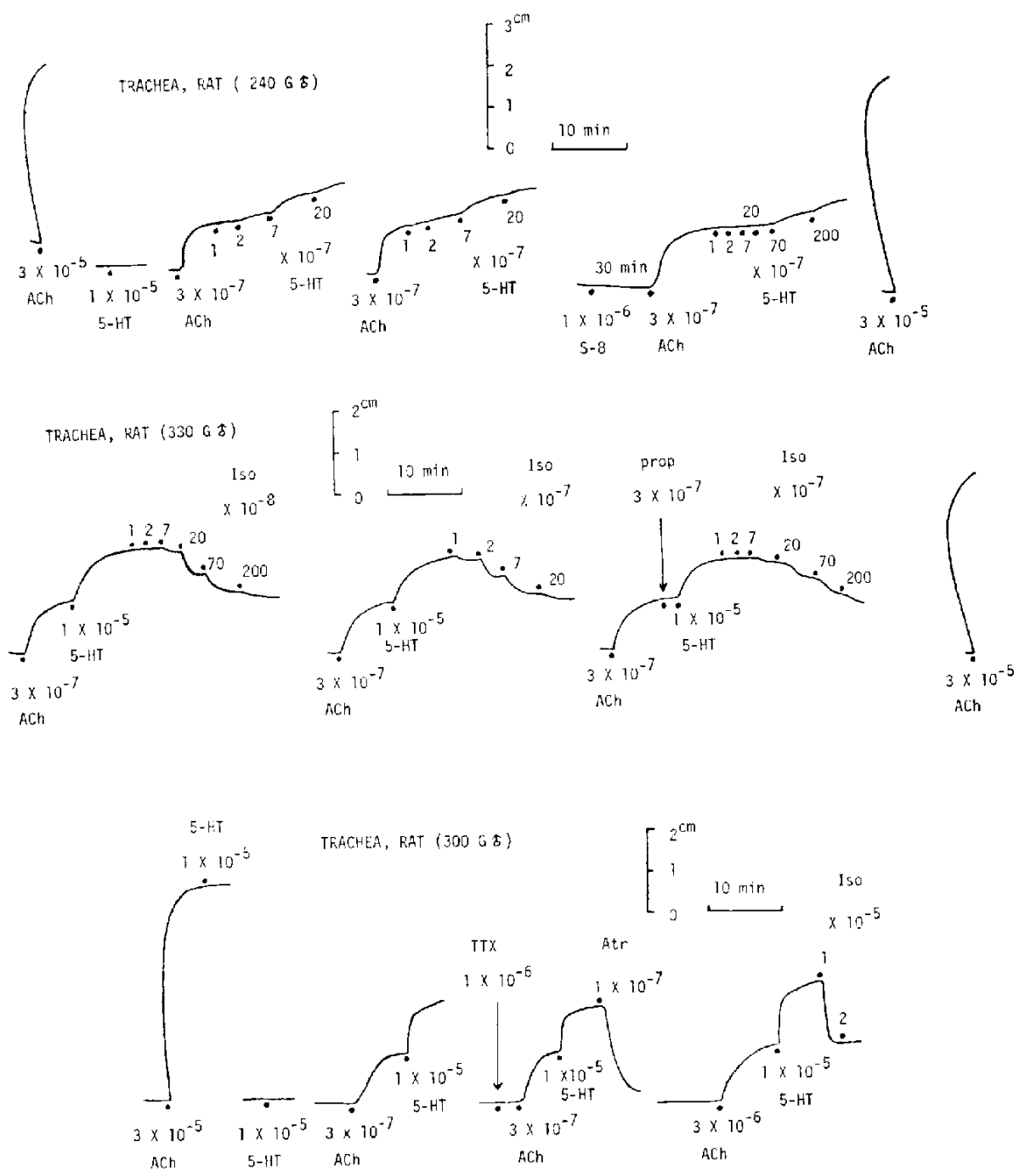

FIG. 6. Effects of various drugs on a further contraction induced by 5-HT in the presence of ACh. Experimental results were obtained after response to 5-HT was abolished by repeated application.

upper: Antagonism between 5-HT and N-benzyl-5-methoxytryptamine $\mathrm{HCl}$ (S-8).

middle : Inhibition of 5-HT-induced contraction by isprenaline (Iso) and antagonism between isoprenaline and propranolol (Prop).

lower: Effects of atropine (Atr), isoprenaline (Iso) and tetrodoxin (TT) on the 5-HT-induced contraction in the presence of ACh. 
completely inhibited by atropine (Fig. 6), while the response to 5-HT in the absence of ACh was little affected by atropine.

When $\mathrm{KCl}\left(3 \times 10^{-3} \mathrm{~g} / \mathrm{ml}\right)$ replaced $\mathrm{ACh}$, similar results were obtained, however a further contraction by 5 -HT in the presence of $\mathrm{KCl}$ was not blocked by atropine $\left(1 \times 10^{-7}\right.$ $\mathrm{g} / \mathrm{ml}$ ) (Fig. 5).

2. Acetylcholine $(A C h)$

Dose-response curve of ACh $\left(1 \times 10^{-7}\right.$ to $\left.3 \times 10^{-5} \mathrm{~g} / \mathrm{mll}\right)$ was displaced parallel toward its high concentrations by atropine $\left(10^{-7} \mathrm{~g} / \mathrm{ml}\right)$, indicating competitive antagonism, however, isoprenaline (up to $3 \times 10^{-5} \mathrm{~g} / \mathrm{ml}$ ) was without any effect on the response to $\mathrm{ACh}$.

3. Other drugs

Histamine (up to $3 \times 10^{-5} \mathrm{~g} / \mathrm{ml}$ ) and phenylephrine (up to $3 \times 10^{-4} \mathrm{~g} / \mathrm{ml}$ ) did not contract the rat tracheal muscle.

\section{DISCUSSION}

In the guinea pig ileum, contraction induced by 5 -HT is mediated through two kinds of receptors (3). One, M-receptor, which is present in nervous structures, can be blocked by morphine, tetrodotoxin and atropine. The other, D-receptor, which is in the smooth nuscle fibres, can be blocked by dibenzyline and so-called 5-HT inhibitors. In this study response of the rat trachea to 5-HT was blocked by S-8, an inhibitor of 5-HT but not by tetrodotoxin, atropine and morphine. These facts suggest that response of the rat tracheal muscle to 5-HT was not mediated through the ACh-release but due to stimulation of 5-HTreceptor in the smooth muscle. It has been clcarly demonstrated, however, by Offermeier and Ariens (4) that in guinea pig trachea response to 5-HT was mediated via the receptor in the cholinergic nerve structures. Difference between our results and the aforementioned in the site of action of 5-HT may be due to species difference.

In preparations where response to 5-HT was abolished by repeated application, further contraction by 5-HT in the presence of ACh was also mediated through 5-HT-receptor in the smooth muscle, as response to 5-HT in the presence of ACh was affected by antagonists in the same manner as that observed on preparations where tachyphylaxis did not occur. Since further contraction by 5-HT in the presence of ACh was abolished by atropine, it can be assumed that further contraction by 5-HT in the presence of ACh is concerned with activation of the $\mathrm{ACh}$ receptor, however, when $\mathrm{KCl}$ was used instead of $\mathrm{ACh}$, a further contraction by 5-HT was also obtained. It can therefore be considered that muscle contraction produced by stimulating drugs induces conformational changes in the cell membrane and that new receptors for 5-HT are uncovered or that desensitized receptors of 5-HT have been resensitized.

The fact that isoprenaline inhibits only the contraction by 5-HT but not that by ACh suggests that the contraction process after formation of 5-HT-receptor complexes may be different from that after formation of ACh-receptor complexes. 


\section{SUMMARY}

The response of the isolated rat trachea to 5-hydroxytryptamine (5-HT) was inhibited by N-benzyl-5-methoxytryptamine (S-8), an inhibitor of 5-HT and isoprenaline but not by tetrodotoxin, atropine and morphine, indicating that $5-\mathrm{HT}$ acts via the $5-\mathrm{HT}$ receptor in the smooth muscle. In the preparation where response to 5-HT was abolished by repeated exposure, 5-HT added in the presence of $\mathrm{ACh}$ or $\mathrm{KCl}$ caused a further contraction. A possible mechanism for this phenomenon was discussed in this paper.

\section{REFERENCES}

1) Takagi, K., Takayanagi, I. and Fujie, K.: Chem. Pharm. Bull. 6, 716 (1958)

2) Takagi, K., Takayanagi, I., Irikura, T., Nishino, K., Ito, M., Ohkubo, H. and Ichinasekt, N.: Jap. J. Pharmac. 19, 234 (1968)

3) Gaddum, J.H. and Picarelli, Z.P.: Br. J. Pharmac. Chemother. 12, 323 (1957)

4) Offermeter, J. And Ariens, E.J.: Arch. int. Pharmacodyn. Therr. 164, 192 (1966) 